\title{
Penyederhanaan ISO 14001:2015 Sebagai Inovasi dalam Monitoring Lingkungan dan K3 di Industri Kecil Menengah
}

\author{
Aditya Prana Iswara1 dan Rachmat Boedisantoso2 \\ 1 Dosen Teknik Lingkungan, Fakultas Teknik, Universitas Pembangunan Nasional "Veteran” Jawa Timur \\ 2 Dosen Teknik Lingkungan, Fakultas Teknik Sipil dan Perencanaan, Institut Teknologi Sepuluh \\ Nopember*ade_ee7@yahoo.com
}

\begin{abstract}
Abstrak
ISO 14001:2015 merupakan revisi dari edisi ISO 14001:2004 yang berisi sistem monitoring dan dokumentasi lingkungan menyeluruh ke semua lini sistem perusahaan. ISO 14001:2015 memiliki klausul yang lebih fleksibel dibandingkan edisi sebelumnya. Penerapan ISO 14001:2015 masih jarang dilakukan oleh industri dan hingga saat ini masih dalam taraf sosialisasi. Beberapa industri besar sudah mulai menjajaki untuk melakukan standarisasi lingkungan menggunakan ISO 14001:2015. Namun sertifikasi ISO 14001:2015 masih memiliki kendala yang cukup signifikan bagi industri kecil menengah dalam penerapan ISO 14001:2015. Penyederhanaan ISO 14001:2015 merupakan gagasan metode penyederhanaan klausul ISO 14001:2015 yang dikonversi ke dalam regulasi daerah sehingga dapat diterapkan dalam industri kecil menengah sesuai dengan kapasitas yang dimiliki oleh industri sehingga monitoring lingkungan dan K3 dapat memberikan perlindungan lingkungan dan hak K3 karyawan pada khususnya dan memberikan revenue kepada industri yang bersangkutan pada umumnya.
\end{abstract}

Kata kunci: ISO 14001:2015, penyederhanaan, industri kecil menengah.

\section{PENDAhuluan}

ISO 14001 merupakan standar internasional mengenai manajemen lingkungan yang diterbitkan oleh International Organization for Standardization (ISO) yang banyak digunakan untuk perusahaan besar untuk standarisasi lingkungan. Versi lama yang saat ini sering digunakan oleh perusahaan adalah ISO 14001:2004. Versi lama dari ISO 14001:2004 sudah digantikan dengan seri terbaru ISO 14001:2015. ISO 14001 telah menjadi standar yang cukup populer dalam penerapan Environmental Management System (EMS). ISO 14001 sendiri merupakan bukan regulasi kewajiban Negara namun adalah kesepakatan perdagangan global dalam menentukan standar lingkungan yang berkembang menjadi voluntary self-regulation atau standar yang diterapkan secara sukarela di perusahaan [1]. Hingga saat ini pihak berwenang di Indonesia tidak mewajibkan standar ISO 14001 bagi perusahaan karena kompleksitas dari ISO 14001 dan diversitas industri yang berlokasi di Indonesia serta mengurangi kepentingan suatu kelompok dalam monopoli standar lingkungan.

Implementasi penerapan ISO terbukti mampu menambah profit dan sustainability perusahaan. Hal ini bisa dilihat dalam skala perdagangan global dimana jual beli produk harus selalu didasari dengan produksi ramah lingkungan. Perusahaan dengan standar ISO 14001 akan lebih mudah melakukan bisnis di berbagai belahan dunia. Perusahaan yang tidak memiliki standar ISO 14001 lebih sulit melakukan perdagangan dengan perusahaan global karena sistem standarisasi yang berbeda. ISO 14001 dipercaya dapat menyediakan pendekatan sistem terhadap isu lingkungan pada perusahaan. Pertama, perusahaan mengurangi dampak negative lingkungan, selanjutnya sistem ISO 14001 akan menekankan pada continual improvement [2].

Perusahaan kecil menengah selalu identik dengan pelanggaran hukum lingkungan, K3 tidak sesuai, hak karyawan yang tidak dipenuhi dan lain sebagainya. Profit menjadi acuan perusahaan, namun tanpa standar, sustainability dari profit tersebut bisa berkurang setiap tahunnya. Penerapan ISO 14001:2015 menjadi beban bagi perusahan kecil menengah karena membutuhkan sumber daya yang cukup besar. Namun, penyederhanaan klausul ISO 14001:2015 bisa menjadi alternatif bagi perusahaan kecil menengah untuk menerapkan standar EMS bagi perusahaan dengan sumber daya yang minimum.

\section{METODE PENELITIAN}

Metode penelitian yang digunakan adalah observasi lapangan dengan studi beberapa perusahaan yang menggunakan standar ISO 14001 dan perusahaan yang tidak menggunakan standar ISO 14001. Setelah observasi dilakukan, dilakukan analisa data yang menghasilkan pembahasan dan kesimpulan. Gambar 1 menunjukkan skema penelitian yang dilakukan pada studi ini, 


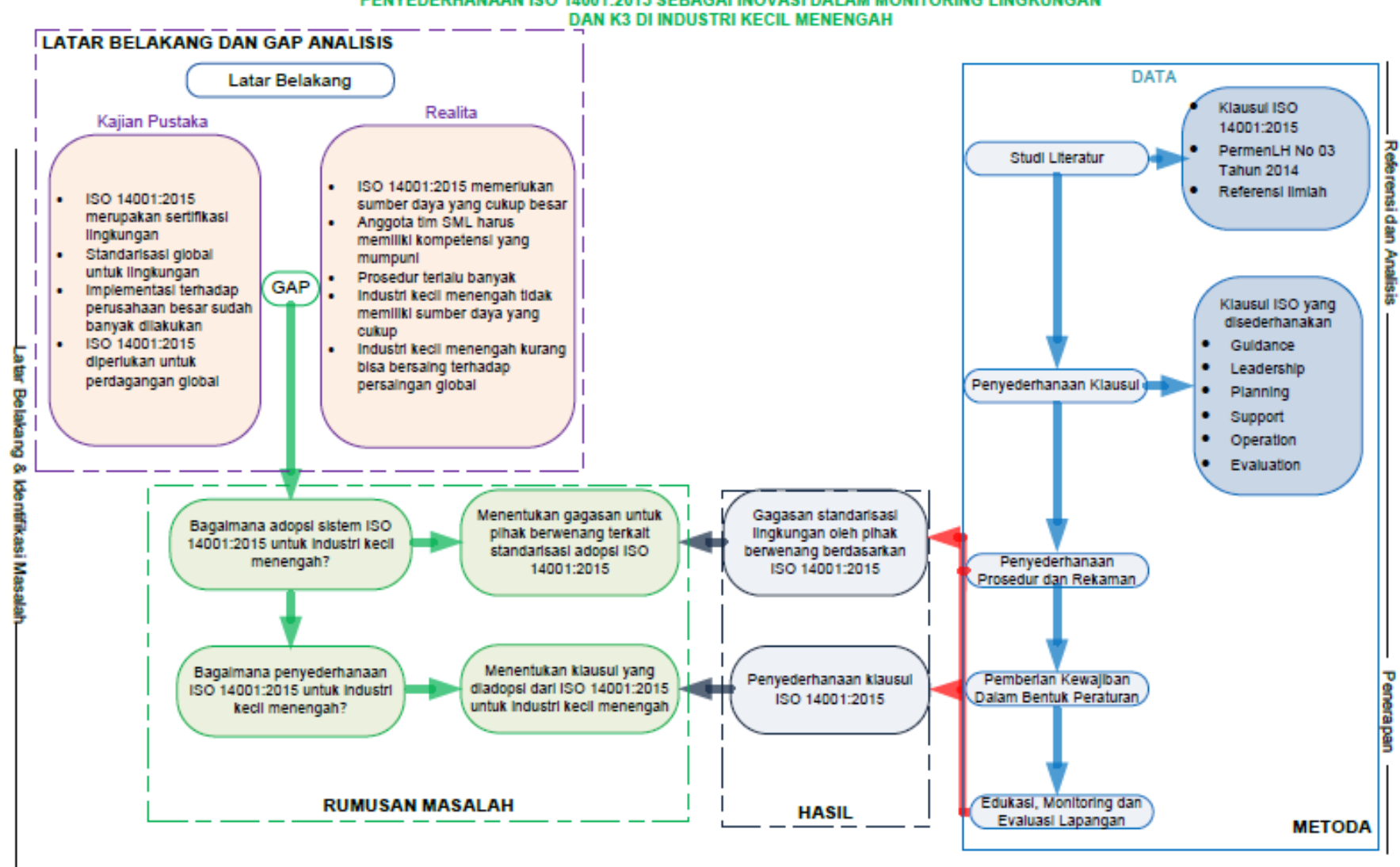

Gambar 1. Kerangka penelitian

\section{PEMBAHASAN}

\subsection{Penyederhanaan Klausul}

ISO 14001:2015 memiliki klausul yang lebih detail dibandingkan dengan ISO 14001:2004. Beberapa klausul ISO mewajibkan beberapa dokumen prosedur yang harus ada dalam sistem perusahaan. Dokumen-dokumen ini merupakan alat bantu dalam sistem manajemen perusahaan terutama untuk recording dan pendokumentasian catatan kinerja lingkungan.

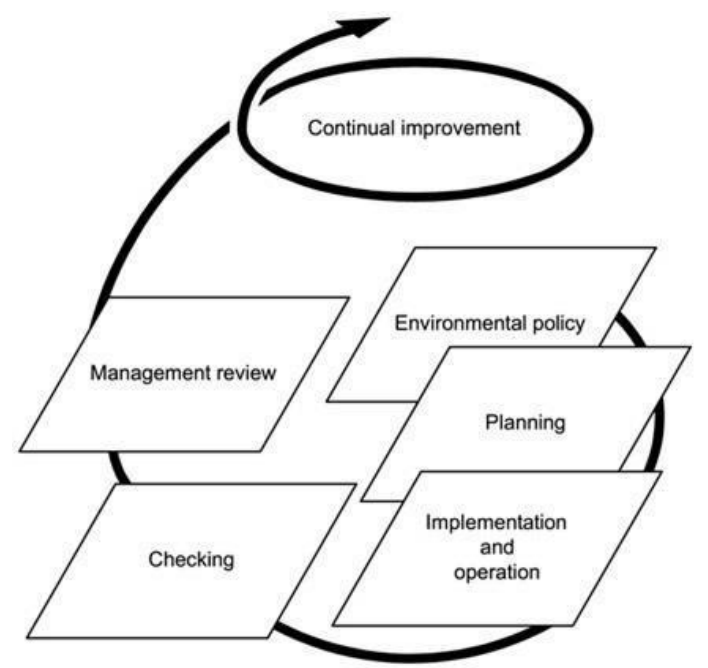

Gambar 2. Continual improvement pada ISO 14001

ISO 14001:2015 berisi klausul yang sangat detail dan ketat sehingga dalam implementasinya memerlukan sumber daya yang cukup besar dan kompeten. Beberapa klausul pemenuhan kewajiban bisa dilakukan dengan sumber daya yang minim. Beberapa inovasi alternatif penyederhanaan ISO 14001 bisa dilakukan dalam klausul tanpa mengurangi esensi dari ISO 14001:2015. Tujuan akhir dari EMS pada ISO 14001:2015 adalah continual improvement atau perbaikan terus menerus. Gambar 2 menunjukkan output continual improvement yang diinginkan oleh sistem ISO 14001. Oleh karena itu, perencanaan, 
penerapan dan evaluasi dilakukan secara terus menerus. Penyederhanaan klausul bisa dilakukan dengan lebih menyederhanakan dokumen yang dipersyaratkan dalam setiap klausul ISO 14001:2015. Untuk mencapai continual improvement, pemerintah wajib memberikan batas minimum pada peraturan wajib yang diadopsi dari klausul ISO 14001:2015. Standar ISO 14001:2015 dirancang sangat fleksible sehingga dapat memenuhi kebutuhan dari perusahaan yang berbeda [3], celah ini bisa dimanfaatkan dalam pembuatan peraturan baku untuk daerah disesuaikan dengan karakter daerah. ISO 14001 diharapkan dapat meningkatkan performa lingkungan: (i) menaati seluruh peraturan lingkungan; (ii) dokumentasi dan analisis dampak lingkungan; dan (iii) sistematik, tertulis dan terstandarisasi dalam mengurangi dan mencegah polusi[1]. Klausul dalam ISO 14001:2015 yang dapat disederhanakan adalah antara lain adalah klausul guidance, leadership, planning, support, operation, dan evaluation. Penyederhanaan prosedur dan rekaman juga dilakukan sebagai upaya untuk mempermudah dokumentasi K3 dan lingkungan.

\subsection{Guidance}

Penetapan struktur organisasi EMS perlu dilakukan untuk mencapai continual improvement. ISO 14001:2015 membagi struktur dalam organisasi EMS untuk organisasi, perencanaan, support dan operasi. Penetapan struktur bisa dilakukan pada perusahaan kecil dan menengah walaupun perusahaan tersebut memiliki sumber daya yang minim. 4 aspek yang dibagi dalam EMS sudah mencakup monitoring lingkungan dan K3 yang dibutuhkan oleh perusahaan.

\subsection{Leadership}

Penetapan komitmen manajemen puncak perlu dilaporkan kepada pihak berwenang sebagai kontrol pemerintah terhadap manajemen perusahaan. Komitmen manajemen puncak dalam ISO 14001:2015 merupakan kewajiban yang harus dipenuhi. Salah satu karakteristik dari ISO 14001 adalah integrasi dan keterlibatan manajemen puncak dalam pendokumentasian kebijakan lingkungan karena manajemen puncak harus mendefinisikan kebijakan lingkungan pada perusahaan [4].

\subsection{Planning}

Perencanaan EMS dilakukan dengan mempertimbangkan isu internal dan eksternal serta kebutuhan dan ekspektasi dari pihak-pihak terkait. Perencanaan juga mencakup potensi kondisi darurat, penaatan peraturan lingkungan dan analisa resiko serta evaluasi efektifitas.

\subsection{Support}

Pemenuhan training wajib bagi karyawan terutama pada aspek K3 dan lingkungan. Hal ini wajib dipenuhi oleh perusahaan kecil menengah dalam rangka pemenuhan hak improvement terhadap karyawan sesuai dengan ISO 14001:2015 [4]. Pihak berwenang dapat menekan perusahaan untuk memberikan training kepada karyawan melalui regulasi dan kebijakan daerah. Edukasi dan persuasi kepada perusahaan mengenai hak training dapat dilakukan terus menerus. Perusahaan dan pemerintah daerah juga dapat bekerja sama dalam pengadaan fasilitas training.

\subsection{Operation}

Proses control, perubahan manajemen dan life cycle selama produksi merupakan faktor penting dalam klausul operasi. Proses operasi perusahaan merupakan aspek yang sulit dikontrol oleh pihak berwenang karena masing-masing perusahaan selalu spesifik

\subsection{Evaluation}

Kewajiban dalam monitoring lingkungan dan pengukuran aspek dampak lingkungan perlu diperhatikan oleh pihak berwenang. Pelaporan monitoring lingkungan harus dilakukan dalam periode tertentu sebagai kontrol pemerintah kepada industri.

Klausul ISO 14001:2015 yang kami sebutkan di atas adalah klausul yang sudah disederhanakan dan dalam implementasinya dapat diwajibkan atau dibuatkan regulasi terhadap industri. Implementasi dari klausul tersebut dapat dilakukan industri kecil menengah dengan sumber daya minimum.

\subsection{Penyederhanaan Prosedur dan Rekaman}

Penyederhanaan prosedur dan rekaman dilakukan untuk mempermudah pencatatan dan dokumentasi monitoring K3 dan lingkungan perusahaan kecil menengah. Gambar 3 menunjukkan penyederhanaan prosedur dan rekaman ISO 14001:2015. Manual ISO tetap dipertahankan sebagai dokumen induk standard di perusahaan kecil menengah. Implementasi prosedur dan rekaman kerja dapat disatukan mengingat prosedur industri kecil menengah memiliki scope yang relatif lebih sempit. 


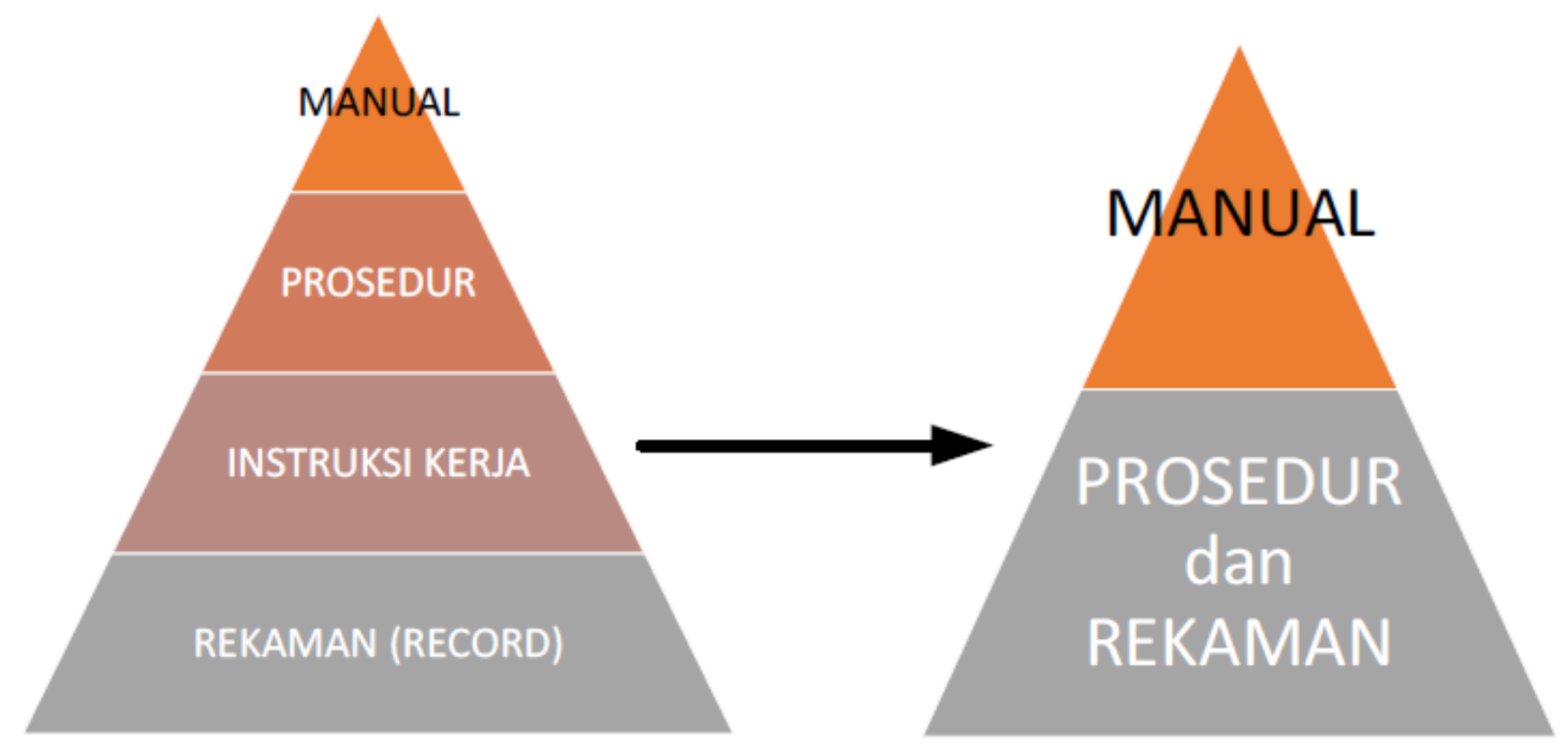

Gambar 3. Skema penyederhanaan prosedur dan rekaman (kiri struktur dokumen ISO 14001:2015; kanan penyederhanaan dokumen dari ISO 14001:2015)

\section{KESIMPULAN}

Monitoring lingkungan dan pemberian hak K3 karyawan dalam industri merupakan hal wajib yang harus dilakukan baik industri besar atau industri kecil menengah. Implementasi ISO 14001:2015 di perusahaan dapat mempermudah pemerintah untuk melakukan monitoring lingkungan dan memastikan karyawan mendapatkan hak K3. Kesulitan implementasi ISO 14001:2015 pada industri kecil menengah dapat ditanggulangi dengan pemberian alternatif oleh pemerintah selaku pemangku kebijakan sesuai dengan kaidah ISO 14001:2015 yang disederhanakan tanpa mengurangi esensi dari ISO 14001:2015.

\section{DAFTAR PUSTAKA}

[1] P. BARLA, “ISO 14001 Certification and Environmental Performance in Quebec's Pulp and Paper Industry," J. Environ. Econ. Manag., vol. 53, pp. 291-306, 2007.

[2] R. J. Jiang and P. Bansal, "Seeing the Need for ISO 14001," J. Manag. Stud., vol. 40, no. 4, pp. 10471067, Jun. 2003.

[3] P. Bansal and T. Hunter, "Strategic Explanations for the Early Adoption of ISO 14001," J. Bussiness Ethics, vol. 46, pp. 289-299, 2003.

[4] M. DELMAS, "Stakeholders and Competitive Advantages: The Case of ISO 14001," Prod. Oper. Manag., vol. 10, no. 3, pp. 343-358, 2001. 